\title{
Infant Development under 6 Months Old in a Family with Smoking Habit
}

\author{
Rufina Adelia Widyatama1 ${ }^{\circledR}$ Irwanto $^{2 *}$, Dwi Susanti ${ }^{3}$
}

${ }^{1}$ Faculty of Medicine, Universitas Airlangga, Surabaya, Indonesia.

2Department of Pediatrics, Faculty of Medicine, Universitas Airlangga, Surabaya, Indonesia.

${ }^{3}$ Department of Public Health and Preventive Medicine, Universitas Airlangga, Surabaya, Indonesia.

\section{A B S T R A C T}

Introduction: Fastest developmental period of infants is on their first six months of life. However, smoking is a habit in Indonesia, done mostly by adult male (47.5\%) on 30-34 years old group (33.4\%) which can harm others, especially their family. Secondhand smoke, defined as environmental smoke that contains more than 4,000 dangerous chemicals, is the major cause of cigarette exposure, and home is the main place where children get exposed. Exposure of secondhand smoke can affect fetal brain, specifically on neurodevelopment stage, which can affect infant development.

Methods: This study used analytic observational with cross sectional approach. Sampling method of the study was cluster sampling. This study involved 103 subjects who came to the selected primary health center. Data of smoking family was collected by interview, and infant's development examination was done by the screening tool Pre-Screening Development Questionnaire (KPSP). Data were analyzed by chi-square correlation test between smoking habit and infant's development.

Results: Number of infants in families with smoking habit were dominant which exposed by father is dominant $(28.1 \%)$, followed by exposure by father and other family members $(25.2 \%)$, and other family members $(7.8 \%)$. Infants that were not exposed by secondhand smoke tend to pass the development test $(67.5 \%)$. There was no significant relationship between infant's development and smoking family habit $(p=0.128)$.

Conclusion: Although the correlation is insignificant, parents should consider family smoking habit due to infants' health and development.

\section{*Correspondence: irwanto.idris@gmail.com}

JUXTA: Jurnal IImiah Mahasiswa Kedokteran Universitas Airlangga

p-ISSN: 1907-3623; e-ISSN: 2684-9453

DOI: $10.20473 / j u x t a . V 12122021.72-76$

Open access under Creative Commons Attribution-ShareAlike 4.0 International License (CC-BY-SA)

\section{ARTICLE INFO}

\section{Article history:}

Received 28 May 2021

Received in revised form 9 July 2021

Accepted 5 August 2021

Available online 31 August 2021

\section{Keywords:}

Health risks,

Healthy lifestyle,

Public health,

Tobacco control. 


\section{Introduction}

Human brain is in its fastest period of development in the first sixth month of life. It will develop many aspects such as a gross motor to control significant muscle ability, fine motor to control small muscle ability, personal-social to control aspects that involve emotions, and language to control language usage such as speaking, singing, and writing. ${ }^{1-4}$ Development is defined as a mental change gradually from the simple to advanced such as intelligence, attitude, and behavior that are measured qualitatitively. ${ }^{5,6}$ Internal factors such as gene, race, gender and external factors including prenatal, natal, and postnatal also influence infants' development. ${ }^{5}$ Furthermore, postnatal factors such as economic status, maternal education, and smoking habit also affect the development of infants. ${ }^{5} \mathrm{WHO}$ declared Indonesia as the third country with the most smoker in the world, and this increased burden of disease, social, economic, affects not only the smoker but also people surrounding the smoker. ${ }^{7,8}$

Secondhand smoke, defined as environmental smoke that contains more than 4,000 dangerous chemicals, is the primary cause of cigarette exposure, and home is the prominent place where children get exposed. 9,10 Exposure to secondhand smoke can affect the fetal brain, specifically in the neurodevelopment stage, which can affect infant development. ${ }^{11}$

Groups of smokers in Indonesia in 2007-2013 were dominated by male $(47.5 \%)$ on $30-34$ years old groups $(33.4 \%) .{ }^{7}$ This can be harmful to children growth and development, especially infant on their fastest period of development. . $^{9} 10,12,13$

The research found bad influences of secondhand smoke exposure such as indications of child behavioral and cognitive vulnerability, severe orofacial clefts, ear infection, cough and cold, acute lower respiratory infection such as bronchitis and pneumonia, and even sudden infant death syndrome (SIDS). This happens because children's bodies are still vulnerable..$^{9,10,14-17}$ Definition of smoker used in this study is smoking cigarettes that produce smoke which affects passive smokers and the environment. ${ }^{7}$

This study aimed to know the correlation between 0-6 months infant's development and smoking family. The hypothesis of this study is a correlation between the smoking habit of family and 0-6-month infant's development. This data may be used to support smoking regulation management in Indonesia.

\section{Methods}

This study was held on May-June 2018 by conducting an analytic observation with a cross-sectional approach to 0-6 month infants. The sampling method of the study was cluster sampling. The study was conducted in Surabaya. Surabaya was divided into five clusters which were North Surabaya, West Surabaya, South Surabaya, East Surabaya, and Central Surabaya. On each cluster, primary health care (Puskesmas) was chosen randomly, and on each primary health care, approximately 10 infants who fulfilled the inclusion criteria were taken as subjects.

The chosen primary health care was Puskesmas Krembangan Selatan for North Surabaya, Puskesmas Simomulyo for West Surabaya, Puskesmas Pucang Sewu for East Surabaya, Puskesmas Kedurus for South Surabaya, and Puskesmas Kedungdoro for Central Surabaya. The study was approved by the Ethics Committee, Faculty of Medicine, Universitas Airlangga, Surabaya, Indonesia.

\section{Recruitment and Study Procedures}

Inclusion criteria of subjects are healthy 3-6 months old infants on the selected primary health care. Healthy means the infant was not suffering any disease at the moment of examination, no muscular or nervous disability including any diseases that have been diagnosed, no history of seizure, no genetic diseases that are related to infant's development such as Down syndrome, Cerebral Palsy, Hydrocephalus, or any disease that has been mentioned prior. The infant's mother, who agreed to their child being a subject and understands this study's procedures, should fill informed consent form. The minimum sample size is 58 infants $(P 1=0.403$ and $P 2=0.139){ }^{18}$ which was calculated according to the WHO sample size application. ${ }^{19}$

Interview and infant's development examination collected data on the smoking family was done by Indonesia's screening tool of Pre-Screening Development Questionnaire (KPSP). ${ }^{19}$ KPSP that was used in this study is suitable for 3 and 6 months' infants. Determining the infant's age is essential to select the proper test because it consists of 16 development tests with 3 months for each range (3-72 months). The infant's age should be 3 months at a minimum. If the infant's age is 3 months 15 days old, it is considered 3 months old; therefore, the test should be taken for 3 months. If the infant's age is in between, the test should be taken for the lower age. The scoring system is by counting the 'yes' answer and interpreted into 3 categories: pass (9-10), suspect $(7-8)$, and fail $(<6) .{ }^{19}$

\section{Data Analysis}

Data were analyzed by a chi-square correlation test between smoking and infant development. Smoking was coded into three categories and combined into two categories in the chi-square analysis; smoking and nonsmoking. $P<0.05$ is considered statistically significant. 


\section{Results}

Table 1. Family smoking habit

\begin{tabular}{lcc}
\hline $\begin{array}{c}\text { Development } \\
\text { Categories }\end{array}$ & Frequency (n) & (\%) \\
\hline No smoking member & 40 & 38.9 \\
Father & 29 & 28.1 \\
Father and other & 26 & 25.2 \\
Family members & 8 & 7.8 \\
Other family members & 103 & 100.0 \\
\hline \multicolumn{1}{c}{ Total } & &
\end{tabular}

107 mothers agreed to participate. Four subjects were excluded because one subject was diagnosed with Down Syndrome, one subject suffered from a seizure, and two others were born prematurely. From 103 subjects, 40 (38.9\%) subjects admitted no members of their family were smoker, $29(28.1 \%)$ subjects admitted exposure to cigarette smoke from their father, $26(25.2 \%)$ subjects from their father and other family members, and 8 (7.8\%) subjects from other family members (Table 1).

Table 2. Development based on KPSP examination

\begin{tabular}{ccc}
\hline $\begin{array}{c}\text { Development } \\
\text { Categories }\end{array}$ & Frequency (n) & (\%) \\
\hline Failed & 27 & 26.2 \\
Suspect & 10 & 9.7 \\
Passed & 66 & 64.1 \\
Total & 103 & 100.0 \\
\hline
\end{tabular}

Based on Table 2, number of infants that passed on KPSP test were dominant $(64.1 \%)$.

Table 3. Correlation between breastfeeding and infant's development

\begin{tabular}{lccccc}
\hline & $\begin{array}{c}\text { Appropriate } \\
\text { Development }\end{array}$ & \multicolumn{2}{c}{$\begin{array}{c}\text { Inappropriate } \\
\text { Development }\end{array}$} & $\boldsymbol{p}^{*}$ \\
\cline { 2 - 5 } & $\mathbf{f}$ & $(\%)$ & \multicolumn{1}{c}{$\mathbf{f}$} & $(\%)$ & \\
\hline $\begin{array}{l}\text { Non-smoking } \\
\text { family } \\
\text { member }\end{array}$ & 30 & 29.1 & 10 & 9.7 & \\
$\begin{array}{l}\text { Smoking } \\
\text { family } \\
\text { members }\end{array}$ & 38 & 36.9 & 25 & 24.3 & \\
\hline
\end{tabular}

${ }^{*}$ Chi-Square

This study shows insignificant correlation between infant's development and family smoking habit $(p=0.128)$ (Table $3)$. However, Table 4 shows numbers of infants that passed on the KPSP development test were higher on nonsmoking family members (67.5\%).

Table 4. Family smoking habit and infants' development

\begin{tabular}{lcccccccc}
\hline & $\begin{array}{c}\text { Failed } \\
(<6)\end{array}$ & \multicolumn{2}{c}{$\begin{array}{c}\text { Suspect } \\
(\mathbf{7 - 8})\end{array}$} & \multicolumn{2}{c}{$\begin{array}{c}\text { Passed } \\
(\mathbf{9 - 1 0 )}\end{array}$} & \multicolumn{2}{c}{ Total } \\
\cline { 2 - 8 } & $\mathbf{f}$ & $\mathbf{( \% )}$ & $\mathbf{f}$ & $\mathbf{( \% )}$ & $\mathbf{f}$ & $\mathbf{( \% )}$ & $\mathbf{f}$ & $(\%)$ \\
\hline $\begin{array}{l}\text { Non- } \\
\text { smoking } \\
\text { family }\end{array}$ & 11 & 27.5 & 2 & 5.0 & 27 & 67.5 & 40 & 100.0 \\
$\begin{array}{l}\text { member } \\
\text { Smoking } \\
\text { family } \\
\text { member }\end{array}$ & 16 & 25.4 & 10 & 15.9 & 37 & 58.7 & 63 & 100.0 \\
\hline
\end{tabular}

\section{Discussion}

Cigarette smoke contains toxic chemicals such as nicotine, tar, and carbondioxide. ${ }^{20}$ Infants exposed to nicotine prenatally are confirmed to show problems on the anterior cingulate cortex that control(s) cognitive and emotional function. This problem leads to ADHD symptoms and novelty-seeking behavior. ${ }^{21}$ Postnatal nicotine exposure also confirms the same problems on cognitive and behavioral functions. Children exposed to secondhand smoke in the postnatal stage tend to have lower grades at school and suffer from cognitive impairment because of concentration difficulties. Behavioral problems such as conduct disorder show up more often in children expose to secondhand smoke than in children with no secondhand smoke expose. ${ }^{22}$ Secondhand smoke exposure on postnatal stage are also confirmed to have a significant correlation on the fine motor $(p=0.004)$ and problemsolving skills $(p=0.013) \cdot{ }^{11}$

This study found that the majority of infants in Surabaya are mostly exposed to cigarette's smoke from their father $(28.1 \%)$, father and other family members $(25.2 \%)$, or other family members $(7.8 \%)$ (Table 1$)$, which is in line with the fact that house is the primary place children got exposed from secondhand smoke by male members of their family, mostly father. ${ }^{10,23}$ The development of infants in Surabaya mostly passed the KPSP test (64.1\%) (Table 2). Secondhand smoke contains a lot of toxic chemicals that, if inhaled by infants, may cause many health problems, such as ear infection, cough and cold, acute respiratory infections, lung cancer, heart diseases, learning and attention disorder, and even SIDS. ${ }^{9,10,12}$

Although this study shows no correlation between child development and family smoking habit $(p=0.128)$, the number of infants that passed the KPSP development test was higher on the non-smoking family member (67.5\%) than infants with a smoking family member (58.7\%). Infants with no smoking family members developed less inappropriately $(9.7 \%)$ compared to infants with a smoking family member $(24.3 \%)$ (Table 3 ). Infants with smoking family members are more significant in number for failed and suspect development tests for 26 subjects. This can prove that secondhand smoke affects infants' development indirectly. However, the insignificant result of this study may be caused by the number of higher on a smoking family member than the non-smoking family member. Family should give more concern about smoking family members while having children inside the house, especially male members of the family such as father, grandfather, brother and uncle due to the cognitive, behavior, fine motor, and problem-solving skill of children already explained above. Health problems, especially development, can cause a burden for the family because of hospital cost in the short terms and low income in the long terms. ${ }^{11,23}$ However, a study has been proved that people with psychiatric conditions and socioeconomic disadvantage are more 
prone to addiction and have more difficulty quitting their addiction. $^{24}$

Campaigns against smoking have been done for years. The Indonesian government also passes regulations against smoking around pregnant women and children because of the dangerous effects. However, government's solutions such as no smoking area, promote harmful effects of cigarettes on cigarette boxes, and limitation of cigarettes promotion is only limited on public area. ${ }^{25}$ Government should be more concerned about secondhand smoke found mainly inside the house and done by parents. The harmful effect on an infant's cognitive development could be a burden for the government because of young generation quality degradation and health burdens.

\section{Conclusion}

Based on the result of the study, we agree that smoking, especially secondhand smoke, can have a bad influence on infant development. Therefore, parents should reconsider their smoking habit due to its effects on infants' health and development.

\section{CONFLICT OF INTEREST}

The author stated there is no conflict of interest in this study.

\section{REFERENCES}

1. Ariyanti F, Edia L, Noory K. Diary Tumbuh Kembang Anak Usia 0-6 Tahun: Tinjauan Psikologis. 2nd ed. Bandung: Read! Publishing House, 2007.

2. Fitriana IR, Margawati A. Hubungan Riwayat Pemberian Asi dan Berat Badan Lahir dengan Perkembangan Motorik Kasar dan Perkembangan Motorik Halus Bayi Usia 6-12 Bulan. J Nutr Coll Vol 5, No 3 JuliDO - 1014710/jnc.v5i316394.

3. Gunawan G, Fadlyana E, Rusmil K. Hubungan Status Gizi dan Perkembangan Anak Usia 1 - 2 Tahun. Sari Pediatr 2016; 13: 142

4. Herr J. Working with Young Children. Tinley Park, III.: Goodheart-Wilcox Co., 2012.

5. Sari RT. Perbedaan Perkembangan Motorik Kasar Bayi 0-6 Bulan yang diberi ASI Eksklusif dan Non ASI Eksklusif di Kelurahan Mulyorejo Wilayah Kerja Puskesmas Mulyorejo Surabaya. Universitas Airlangga, 2013.

6. Permono H. Peran Orangtua dalam Optimalisasi Tumbuh Kembang Anak untuk Membangun Karakter Anak Usia Dini. In: Seminar Nasional Psikologi UMS 2013. Surakarta: Universitas Muhammadiyah Surakarta, 2013, pp. 34-47.

7. Indonesia KKR. Riset Kesehatan Dasar 2013. Jakarta, 2013.

8. Indonesia KKR. Buku Profil Kesehatan Indonesia 2015. Jakarta, 2015.

9. Pediatrics AA of. The Dangers of Secondhand Smoke. healthychildren.org, https://www.healthychildren.org/English/healthissues/conditions/tobacco/Pages/Dangers-ofSecondhand-Smoke.aspx (2014).

10. Prevention $\mathrm{C}$ for $\mathrm{DC}$ and. Children in the Home. $C D C$ 24/7: Saving Lives, Protecting People ${ }^{T M}$, https://www.cdc.gov/tobacco/basic information/se condhand_smoke/children-home/index.htm (2018).

11. Mohamed NN, Loy SL, Lim PY, et al. Early Life Secondhand Smoke Exposure Assessed by Hair Nicotine Biomarker May Reduce Children's Neurodevelopment at 2 Years of Age. Sci Total Environ 2018; 610-611: 147-153.

12. General USPHSO of the S. The Health Consequences of Involuntary Exposure to Tobacco Smoke: A Report of the Surgeon General. U.S. Department of Health and Human Services, Public Health Service, Office of the Surgeon General, 2006.

13. Syahputra H, Sabrian NF, Utomo W. Perbandingan Kejadian ISPA Balita pada Keluarga yang Merokok di Dalam Rumah dengan Keluarga yang Tidak Merokok. J Keperawatan Komunitas 2018; 2: 714.

14. Tzoumakis S, Carr VJ, Dean K, et al. Prenatal Maternal Smoking, Maternal Offending, and Offspring Behavioural and Cognitive Outcomes in Early Childhood. Crim Behav Ment Health 2018; 28: 397-408.

15. Schulte-Hobein B, Schwartz-Bickenbach D, Abt S, et al. Cigarette Smoke Exposure and Development of Infants throughout the First Year of Life: Influence of Passive Smoking and Nursing on Cotinine Levels in Breast Milk and Infant's Urine. Acta Paediatr 1992; 81: 550-557.

16. Luk TT, Wang MP, Suen YN, et al. Early Childhood Exposure to Secondhand Smoke and Behavioural Problems in Preschoolers. Sci Rep 2018; 8: 15434.

17. Bui AH, Ayub A, Ahmed MK, et al. Maternal Tobacco Exposure and Development of Orofacial Clefts in the Child: A Case-Control Study Conducted in Pakistan. Ann Plast Surg 2018; 81: 708-714.

18. Khoiriyah $\mathrm{H}$. Hubungan Pemberian ASI Eksklusif dengan Perkembangan Bayi Usia 6-12 Bulan di Kelurahan Sumbersari Wilayah Kerja Puskesmas Sumbersari Bantul Metro Selatan Periode Februari-April Tahun 2017. J Kesehat; 2.

19. Indonesia KKR. Instrumen Deteksi Dini Penyimpangan Perkembangan pada Balita dan Anak Prasekolah. Jakarta, 2007.

20. Tirtosastro S, Murdiyati AS. Kandungan Kimia Tembakau dan Rokok. Bul Tanam Tembakau, Serat Miny Ind 2010; 2: 33-43.

21. Holz NE, Boecker R, Baumeister S, et al. Effect of Prenatal Exposure to Tobacco Smoke on Inhibitory Control: Neuroimaging Results from a 25-year Prospective Study. JAMA Psychiatry 2014; 71 : 786-796.

22. Zhou S, Rosenthal DG, Sherman S, et al. Physical, Behavioral, and Cognitive Effects of Prenatal Tobacco and Postnatal Secondhand Smoke Exposure. Curr Probl Pediatr Adolesc Health Care 2014; 44: 219-241.

23. Reece S, Morgan C, Parascandola $\mathrm{M}$, et al. Secondhand Smoke Exposure during Pregnancy: A Cross-Sectional Analysis of Data from Demographic and Health Survey from 30 LowIncome and Middle-Income Countries. Tob Control 2019; 28: 420 LP - 426.

24. Higgins ST, Heil SH, Sigmon SC, et al. Addiction Potential of Cigarettes with Reduced Nicotine Content in Populations with Psychiatric Disorders and Other Vulnerabilities to Tobacco Addiction. JAMA Psychiatry 2017; 74: 1056-1064. 
25. Indonesia PR. Peraturan Pemerintah Republik Indonesia Nomor 109 Tahun 2012 tentang Pengamanan Bahan yang Mengandung Zat Adiktif Berupa Produk Tembakau Bagi Kesehatan. Jakarta: Pemerintah Republik Indonesia, 2012. 